\title{
UPPER JURASSIC-CRETACEOUS STRATIGRAPHY OF THE VLIELAND BASIN, AND ADJACENT AREAS, THE NETHERLANDS
}

\section{Extended Abstract}

\author{
G. F. W. Herngreen, R. Smit \& Th .E. Wong \\ Geological Survey of The Netherlands, P.O. Box 157, 2000 AD Haarlem, The Netherlands
}

\section{Introduction}

This contribution presents an extended abstract intended for the proceedings of the symposium: The Jurassic in the southern Central Graben, Hørsholm, (Denmark) June 15-16, 1989. The full text entitled "Tectonostratigraphic development of the Vlieland Basin. The Netherlands" will appear in the Proceedings 1st Conference European Association of Petroleum Geoscientists (Berlin: May 29th - June 2nd, 1989).

The Vlieland Basin is located in the northern Netherlands; it covers the NW'ern part of the province of Friesland to the offshore area of the Frisian Island of Vlieland. It is a NW-SE striking structure which is bounded to the W, S and SE by the TexelIJsselmeer High, and flanked by the Vlieland High, an extension of the Schill Grund High, in the north, and the North Netherlands High in the east.

In the Vlieland Basin the major Zuidwal gasfield is located, which recently started production from the Lower Cretaceous Vlieland Sandstone.

\section{Stratigraphic Development}

Jurassic-Cretaceous boundary strata of latest Kimmeridgian to Ryazanian age, were mainly deposited in a terrestrial, and partly near coastal, environment. They are assigned to the Delfland Formation. The upper part of the formation is developed in a (?paralic) coal facies in the area between wells Vlieland Oost-1 and Harlingen-1. Volcanic ashes as mentioned in previous publications, are not considered to be primary tuffs, but are thought to represent reworked tuffaceous rocks, the pyroclastic components of which were derived from the Zuidwal-1 Volcano. These strata are included in the Wadden Volcanoclastic Member, of the Delfland Formation (Central Graben Group).

The Delfland strata are concentrated in two depocentres: The prominent northern and southern subbasins which are separated by the Zuidwal-1 volcanic plug and dome. It is apparent from a stripped basement profile, constructed after decompaction and unloading that the northern subbasin subsided more than the southern subbasin. In well Vlieland Oost-1 Delfland deposits of Portlandian-Ryazanian age are underlain by marine strata of the Kimmeridge Clay Formation (Scruff Group), dated as late Early to Late Portlandian.

It is concluded that the Zuidwal-1 volcano acted as a barrier between the two Vlieland subbasins. It separates the marine realm (Scruff Group) of the SE extension of the Central North Sea Graben from the terrestrial environment (Delfland Formation) of the southern Vlieland Subbasin.

In some wells (Vlieland Oost-1 and Har- 
lingen-1) the upper part of the Delfland Formation is of Early Ryazanian age: in several other wells indications for this dating are found. This suggests that a hiatus, representing the pre-Albidum Late Ryazanian, may exist throughout the entire study area.

The Vlieland Formation extends to the east as far as Leeuwarden, and hence well beyond the area of sedimentation of the Jurassic/Cretaceous boundary strata of the Delfland Formation. In the Leeuwarden area the Lower Cretaceous rests unconformably on Triassic or Zechstein strata.

The Lower Cretaceous transgression started in latest Ryazanian time, equivalent to the Albidum ammonite-zone. Most likely brackish deposits near the base, and nearshore marine sandstones of Valanginian age, form the Vlieland Sandstone Member of the Vlieland Formation. The Vlieland Sandstone is a major reservoir rock for gas in the northern Netherlands.

Around the Valanginian/Hauterivian boundary a remarkably thin sedimentary sequence (e.g. Zuidwal-2) is found within the Vlieland Shale Member. This may be explained by small hiatuses and/or by a condensed sequence. This level concides with a marked hiatus extending from the Late Valanginian to the Early Hauterivian in the Leeuwarden area. The younger Hauterivian and Barremian shales of the Vlieland Shale Member, which were deposited in a more open marine offshore shelf facies, show no major breaks in sedimentation. The Vlieland shales form an effective seal for the Vlieland Sandstone reservoir rock.

The typical tripartite subdivision of the Holland Formation (a mainly marly sequence of Aptian to Albian age) is well developed in the studied area. A major regional hiatus - representing at least the Lower Aptian - is present near the base of the Holland Formation. This unconformity includes the entire Aptian in the Leeuwarden area, where red rocks of Albian age rest on Barremian sediments.

Finally, the Upper Cretaceous Texel and Ommelanden Chalk Formations are re- markably thin (up to about $200 \mathrm{~m}$ ) in the area of the Vlieland Basin. An unconformity at the top of the Ommelanden Chalk separates Tertiary from Lower Maastrichtian strata; also other hiatuses could be demonstrated in the Upper Cretaceous sequence. Outside the Vlieland Basin, a fairly thick Upper Cretaceous $(500 \mathrm{~m}$ in Barradeel-1) and Lower Cretaceous sequence occurs, resting on Triassic rocks. The differences in thickness of the Upper Cretaceous limestones reflect tectonic inversion.

\section{Tectonic Development}

The structural evolution of the Vlieland $\mathrm{Ba}$ sin is not fully understood. It underwent a number of events related to Variscian, Kimmerian, and Alpine tectonism. It seems likely that a sequence of interrelated factors contributed to the development of this small basin:

1. NW-SE oriented strike-slip faults, initiating the formation of a small pull-apart basin, accompanied by volcanism (Zuidwal-1 volcano);

2. Loading effect of the Zuidwal volcano;

3. Thermal relaxation;

4. Loading by sediments;

5. Minor withdrawal, dissolution or subrosion of Zechstein salt.

It is assumed that there is an interrelationship between the Vlieland Basin and the major geological structures surrounding it, in particular the Central North Sea Graben (CNSG) and the Lower Saxony Basin (LSB). The link is in the form of an as yet ill-defined, partly speculative, transform fault zone passing north of the Texel-IJsselmeer High (TYH). A stable "Northwest German Block" rotated anti-clockwise with respect to the TYH and areas west of the CNSG and south of the LSB, causing rightlateral slip along a diffuse transform fault zone. Approximately NW-SE striking Carboniferous faults are thought to have been 
reactivated in latest Middle or earliest Late Jurassic times.

\section{Conclusions/Summary}

1. The Vlieland Basin is considered to be a pull-apart basin, tectonically related to the Central North Sea Graben and the Lower Saxony Basin.

2. The Vlieland Basin, with mainly Portlandian and Ryazanian infilling, is a relatively young basin as compared with the Central North Sea Graben, where sedimentation started in Callovian time.
3. During the Portlandian the Zuidwal-1 volcano acted as a barrier separating a marine facies, which is related to the Central North Sea Graben, from a terrestrial one in the southeastern part of the basin.

4. There is no evidence for an Upper Jurassic Lower Saxony facies (calcareous and evaporitic).

5. The Wadden Volcanoclastic sediments, previously considered to be of primary volcanic origin, presumably represent reworked material from the Zuidwal-1 volcano. 